\title{
PERBANDINGAN METODE ARIMA DAN EXPONENTIAL SMOOTHING HOLT-WINTERS UNTUK PERAMALAN DATA KUNJUNGAN
}

\author{
Rumini, Norhikmah \\ Informatika, Fakultas Ilmu Komputer, Universitas AMIKOM Yogyakarta, \\ Jalan Ring Road Utara, Condong Catur, Depok, Sleman, Yogyakarta \\ Email: rumini@amikom.ac.id, hikmah@amikom.ac.id
}

(Diterima: 6 Agustus 2020, direvisi: 17 Agustus 2020, disetujui: 4 September 2020)

\begin{abstract}
A visit to the creative economy park is a place designed using strategic objectives in collaborating technology capabilities, transferring information and knowledge, planting innovative high-tech companies and entrepreneurs, bringing up new technology industries in the creative economy business to drive economic development. Universitas AMIKOM Yogyakarta has been declared a creative economy park and is known as the Amikom Creative Economy Park (ACEP). ACEP includes several multimedia environments for targeting businesses, for example software development, film, television, games, radio, animation, advertising, investment advisory, and project design. The development of the number of visitors from year to year, predictions need to be made to support the planning and preparation process in receiving visits. The data used in this study are visitor data from January 2019 to December 2019. Analysis of visit prediction data using data mining is the Autoregressive Integrated Moving Average (ARIMA) and Exponential Smoothing methods. The research resulted from prediction of the number of visit data for 2020 is more accurate using the Holt-Winters exponential smoothing method with a MAPE value of 47,197 when compared to the ARIMA method with a MAPE value of 48,949 so that the MAPE value generated by the ARIMA method is smaller than the Holt-Winters exponential smoothing method. The results of this study are to provide input in the form of predictions of the number of ACEP visitors in the coming year.
\end{abstract}

Keywords: ARIMA, data mining, exponential smoothing, prediction, visit

\begin{abstract}
ABSTRAK
Kunjungan di taman ekonomi kreatif adalah meruapakan tempat yang dirancang dengan menggunakan tujuan strategis dalam mengkolaborasikan kemampuan teknologi, transfer informasi dan pengetahuan, penanaman perusahaan teknologi tinggi yang inovatif dan wirausaha, memunculkan industri teknologi baru dalam bisnis ekonomi kreatif untuk mendorong perkembangan ekonomi. Universitas Amikom Yogyakarta telah dinyatakan sebagai taman ekonomi kreatif dan dikenal sebagai Taman Ekonomi Kreatif Amikom (ACEP). ACEP mencakup beberapa lingkungan multimedia untuk membidik bisnis, misalnya pengembangan perangkat lunak, film, televisi, game, radio, animasi, iklan, penasehat investasi, dan desain proyek. Perkembangan jumlah pengunjung dari tahun ke tahun, perlu dilakukan peramalan untuk mendukung proses perencanaan dan persiapan dalam menerima kunjungan. Data yang digunakan dalam penelitian adalah data pengunjung pada Januari 2019 sampai Desember 2019. Analisis data peramalan kunjungan menggunakan data mining yaitu dengan metode Autoregressive Integrated Moving Average (ARIMA) dan Exponential Smoothing. Penelitian yang dihasilkan dari peramalan jumlah data kunjungan untuk tahun 2020 lebih akurat menggunakan metode exponential smoothing Holt-Winters dengan nilai MAPE 47,197 jika dibandingkan metode ARIMA dengan nilai MAPE 48,949 sehingga nilai MAPE yang dihasilkan metode ARIMA lebih kecil dari metode exponential smoothing Holt-Winters. Hasil dari penelitian ini adalah memberikan masukan berupa peramalan jumlah pengunjung ACEP ditahun yang akan datang.
\end{abstract}

Kata Kunci: ARIMA, data mining, exponential smoothing, peramalan, kunjungan

\section{PENDAHULUAN}

Kunjungan di taman ekonomi kreatif adalah merupakan tempat yang dirancang dengan menggunakan tujuan strategis dalam mengkolaborasikan kemampuan teknologi, transfer informasi dan 
pengetahuan, penanaman perusahaan teknologi tinggi yang inovatif dan wirausaha, memunculkan industri teknologi baru dalam bisnis ekonomi kreatif untuk mendorong perkembangan ekonomi. Universitas Amikom Yogyakarta telah dinyatakan sebagai taman ekonomi kreatif dan dikenal sebagai Taman Ekonomi Kreatif Amikom (ACEP). ACEP mencakup beberapa lingkungan multimedia untuk membidik bisnis, misalnya pengembangan perangkat lunak, film, televisi, game, radio, animasi, iklan, penasehat investasi, dan desain proyek [1]. Setiap tahun jumlah institusi yang berkunjung ke universitas Amikom Yogyakarta yang memiliki tagline Amikom Creative Economy Park dengan jadwal kunjungan yang cukup ramai. Agenda dalam penerimaan kunjungan ini dilakukan oleh bagian humas Amikom (DKUI, Direktorat Kehumasan dan Urusan Internasional). Perkembangan jumlah pengunjung dari tahun ke tahun, dan setiap bulan perlu dilakukan peramalan untuk mendukung proses perencanaan dan persiapan dalam menerima kunjungan. Peramalan adalah seni dan ilmu untuk memperkirakan kejadian dimasa depan. Hal ini dapat dilakukan dengan melibatkan pengambilan data masa lalu dan menempatkannya kemasa yang akan datang dengan suatu bentuk matematis [2].

Data Mining adalah proses yang menggunakan teknik statistik, matematika, kecerdasan buatan, machine learning untuk mengekstraksi dan mengidentifikasi informasi yang bermanfaat dan pengetahuan yang terkait dari berbagai database besar [3]. Terdapat beberapa istilah lain yang memiliki makna sama dengan data mining, yaitu Knowledge discovery in databases (KDD), ekstraksi pengetahuan (knowledge extraction), Analisa data/pola (data/pattern analysis), kecerdasan bisnis (business intelligence) dan data archaeology dan data dredging[4].

Berdasarkan fungsionalitasnya, tugas-tugas data mining dikelompokkan kedalam enam kelompok berikut ini [5]: (1) klasifikasi (classification), mengeneralisasi struktur yang diketahui untuk diaplikasikan pada data-data baru, misalkan, klasifikasi penyakit kedalam sejumlah jenis; (2) klasterisasi (clustering), mengelompokkan data yang tidak diketahui label kelasnya, ke dalam sejumlah kelompok tertentu sesuai ukuran kemiripannya, (3) regresi, menemukan suatu fungsi memodelkan data dengan galat (kesalahan peramalan) seminimal mungkin, (4) deteksi anomali (anomaly detection), mengidentifikasi data yang tidak umum, dapat berupa outlier (pencilan), perubahan atau deviasi yang mungkin sangat penting dan perlu investigasi lebih lanjut, (5) pembelajaran aturan asosiasi (assosiation rule learning) atau pemodelan kebergantungan (dependency modeling), mencari relasi/hubungan antar variabel, (6) perangkuman (summarization), menyediakan representasi data yang lebih sederhana, meliputi visualisasi dan pembuatan laporan.

Peramalan (forecasting) adalah untuk melakukan prediksi/peramalan berdasarkan variabel independent (bebas) dan variabel dependent (terikat). Dalam Gambar 1 dibawah ini, terdapat struktur dari forecasting menurut makridakis et al, Hane and Reitsch, Wei, W.W.S, BOx, Jenkins and Reinsel bahwa forecasting method terdiri dari objective dan subjective (judgmental).

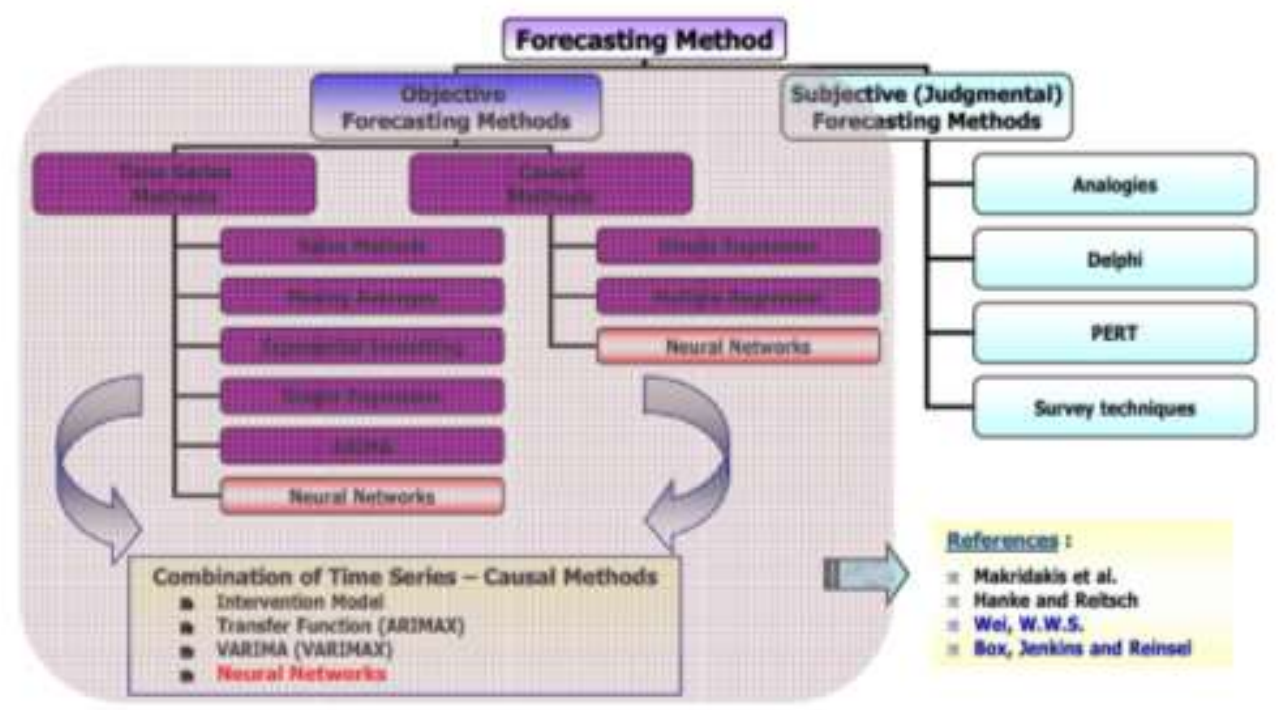

Gambar 1. Forecasting Method 
Pada Gambar. 2 di bawah ini merupakan struktur dari model time series, time series digunakan untuk prediksi berdasarkan waktu, referensi dari Timo Terasvirta, Dag Tjostheim dan Clive W. J. Granger mengemukakan bahwa modelnya terbagi menjadi linear dan non linear, untuk model time series linear diantaranya adalah ARIMA box-jenkins, intervention model, transfer function (ARIMAX) dan VARIMA (VARIMAX), sedangkan model time series nonlinear diantaranya adalah nonlinear autoregressive, neurat network model, state-dependent, nonparametric models dan models from economic theory.
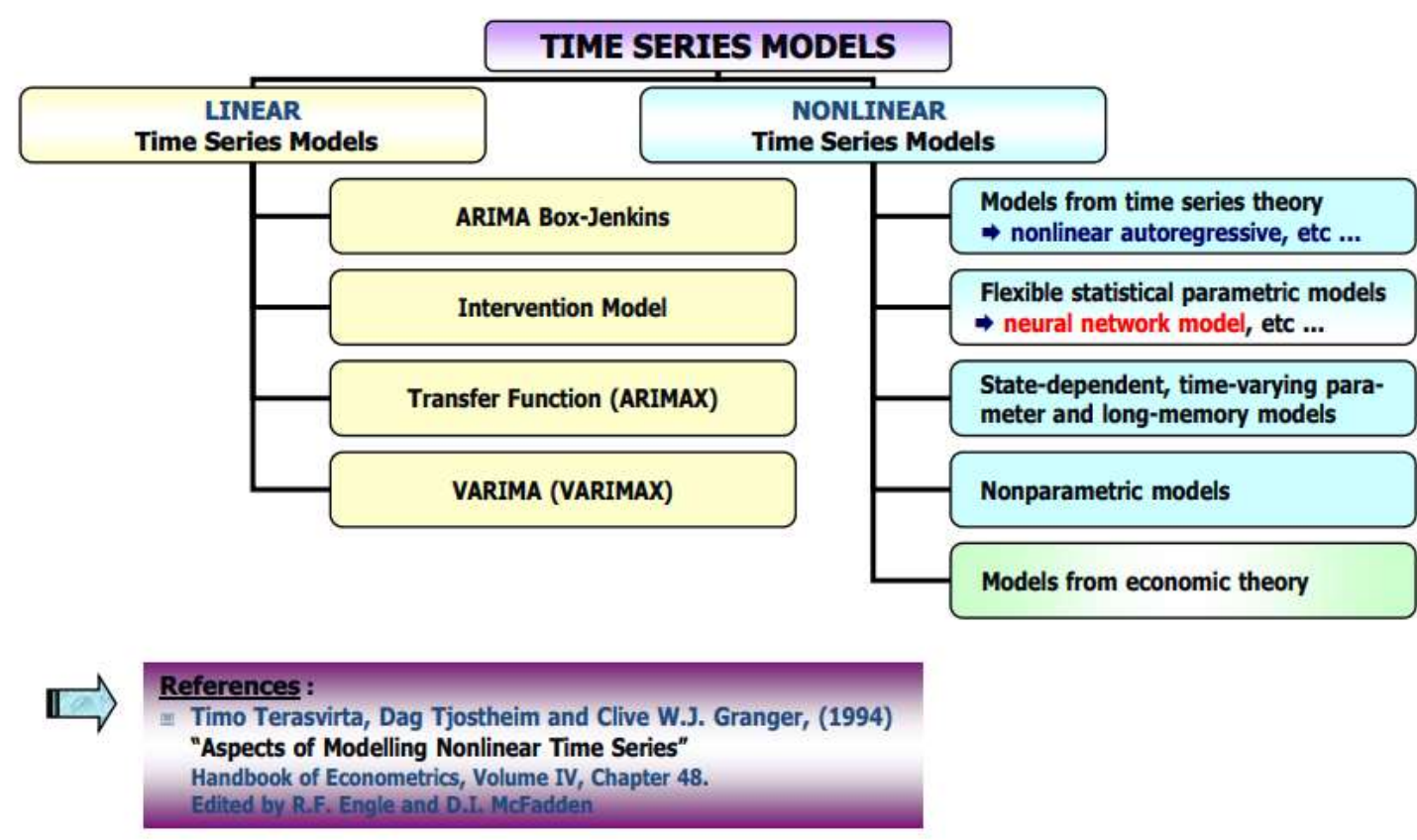

Gambar 2. Time Series Models

ARIMA umumnya disebut dengan metode time series BoxJenkins. ARIMA atau Autoregressive Integrated Moving Average ditemukan oleh George Edward Pelham Box dan Gwilym Meirion Jenkins yaitu metode peramalan untuk menyelesaikan deret berkala untuk menganalisis time series. Metode ARIMA sangat baik digunakan untuk meramalkan data untuk jangka pendek sedangkan untuk peramalan jangka panjang ketepatan terhadap peramalannya kurang baik. Model ARIMA adalah model univariate, sehingga model ini cocok jika observasi dari time series secara statistik tidak berhubungan satu sama lain. Selain menggunakan ARIMA, dalam penelitian ini juga menggunakan metode Exponential Smoothing. Peramalan untuk data musiman dikembangkan dengan menggunakan metode Exponential Smoothing Holt-Winters. Metode Holt-Winters adalah nama sebutan dari metode pemulusan eksponensial triple dimana dilakukan pemulusan tiga kali kemudian dilakukan peramalan. Metode Holt-Winters merupakan perluasan dari dua parameter Holt. Metode Holt-Winters yakni metode peramalan runtun waktu (time series) yang dapat menangani perilaku musiman (seasonal) pada sebuah data berdasarkan pada data masa lalu.

Penelitian ini akan membahas trend pengunjung yang studi banding di Amikom Creative Economy Park di masa yang akan datang. Data yang digunakan dalam penelitian adalah data pengunjung ke ACEP pada Januari 2019 sampai Desember 2019. Analisis data peramalan ini menggunakan Autoregressive Integrated Moving Average (ARIMA), dan Exponential Smoothing Holt-Winters sebagai pembanding untuk tingkat akurasi peramalannya dengan menghitung kesalahan peramalan adalah dengan Mean Squared Error (MSE) dan Mean Absolute Percentage Error (MAPE) sehingga error-nya menjadi seminimal mungkin.

Dengan adanya peramalan kunjungan ini, diharapkan dapat memberikan perencanaan dan persiapan bagi direktorat kehumasan dan urusan internasional universitas AMIKOM Yogyakarta. Kedua metode tersebut dibandingkan untuk melihat metode yang lebih baik dari sisi akurasi dalam peramalan data kunjungan tersebut dengan melihat nilai Mean Absolute Percentage Error (MAPE) dari 
masing-masing metode. Keakuratan dalam memperamalan sangat penting dilakukan, mengingat hasil peramalan dalam suatu data akan dapat digunakan untuk menentukan strategi langkah selanjutnya yang tepat dalam data peramalan yang sudah dilakukan uji analisis. Dalam peramalan data kunjungan ini misalnya, dapat dilakukan langkah yang tepat bagaimana melakukan strategi pelayanan yang dilakukan terkait bertambahnya kunjungan studi di ACEP, agar pengunjung mendapatkan kepuasan serta tujuan yang didapatkan. Peramalan sangat membantu pimpinan dalam melakukan strategi yang bagus dalam pengambilan keputusan.

\section{TINJAUAN PUSTAKA}

Beberapa penelitian yang terkait dengan metode ARIMA dan Exponential Smoothing yang dilakukan oleh peneliti terdahulu di antaranya, peramalan Jumlah Kebutuhan Pemakaian Air Menggunakan Metode Exponential Smoothing (Studi Kasus, PDAM Malang) yang membandingkan 3 metode Exponential Smoothing, yaitu: Single Exponential Smoothing (SES), Double Exponential Smoothing (DES), dan Triple Exponential Smoothing (TES) yang digunakan untuk mendapatkan hasil peramalan dan melakukan evaluasi hasil peramalan dengan metode Mean Absolute Percentage Error (MAPE). MAPE terkecil didapatkan pada saat menggunakan metode Single Exponential Smoothing (SES) pada saat nilai a = 0,2 dengan nilai MAPE sebesar 3,992, metode Double Exponential Smoothing (DES) pada saat nilai $a=0,1$ dengan nilai MAPE sebesar 4,932, dan metode Triple Exponential Smoothing (TES) pada saat nilai $a=0,1, \beta=0,1$, dan $\gamma=0,6$ dengan nilai MAPE sebesar 6,733. Dengan nilai MAPE dibawah 10, maka metode Exponential Smoothing untuk peramalan jumlah kebutuhan air termasuk kedalam kategori sangat baik[6]. Penelitian berikutnya adalah perbandingan peramalan menggunakan metode Exponential Smoothing holt-winters dan arima Analisis data yang digunakan adalah metode Exponential Smoothing Holt-Winters dan ARIMA dengan nilai MSE dan MAPE terkecil. Hasil penelitian menunjukkan bahwa: (1) peramalan dengan metode Exponential Smoothing Holt Winters menghasilkan model dengan nilai MSE 1436553590 dan MAPE 8,86198\%; (2) peramalan dengan metode ARIMA menghasilkan model ARIMA $(2,1,0)(0,1,1) 12$ dengan transformasi logaritma dengan nilai MSE 1353169319 dan MAPE 9,40981\%; dan (3) perbandingan peramalan lebih tepat menggunakan metode Exponential Smoothing Holt-Winters daripada ARIMA karena menghasilkan nilai error lebih kecil daripada nilai error metode ARIMA[7]. Penelitian selanjutnya adalah penerapan metode ARIMA untuk peramalan pengunjung Perpustakaan UIN Suska Riau didapatkan hasil peramalan hingga hari ke 190 yaitu Jurusan Teknik Informatika 10 Mahasiswa, Teknik Industri 1 Mahasiswa, Sistem Informasi 3 Mahasiswa, Matematika Terapan 3 Mahasiswa, Teknik Elektro 2 Mahasiswa dan total perhari 24 Mahasiswa [8].

Perbedaan penelitian ini menggunakan data kunjungan kemudian dilakukan analisis perbandingan peramalan menggunakan metode ARIMA dan Exponential Smoothing dan menggunakan pendekatan kuantitatif yang menekankan analisisnya pada data-data numerikal (angka-angka) dengan pengolahan metode statistik. Pada penelitian ini metode penelitian yang dilakukan dengan cara identifikasi masalah, perumusan masalah, studi pustaka, analisis, tahapan penelitian dan pengambilan kesimpulan. Identifikasi masalah dimulai dengan studi pustaka. Pada tahap ini dilakukan pencarian dan pengumpulan data sekunder dan memilih data sekunder yaitu mengambil data sampel yang dijadikan sebagai permasalahan yang dikaji serta dianalisis. Tahap fokus permasalahan dalam penelitian ini adalah penelitian menggunakan metode Exponential Smoothing Holt-Winters dan ARIMA untuk menghitung peramalan. Penelitian didukung oleh bantuan program Eviews dan SPSS. Data penelitian ini adalah data dalam bentuk bulan dan jumlah kunjungan di ACEP periode Januari 2019 - Desember 2019. Data merupakan jenis data time series yang bersumber dari data kunjungan direktorat kehumasan dan urusan internasional. Teknik yang digunakan untuk meramalkan kunjungan 3 bulan kedepan (sebagai contoh data peramalan) adalah metode Autoregressive Moving Average (ARIMA) dan Exponential Smoothing.

\section{METODE PENELITIAN}

Metode penelitian yang dilakukan untuk menganalisa permasalahan diatas menggunakan metode experiment seperti Gambar 3 di bawah ini : 


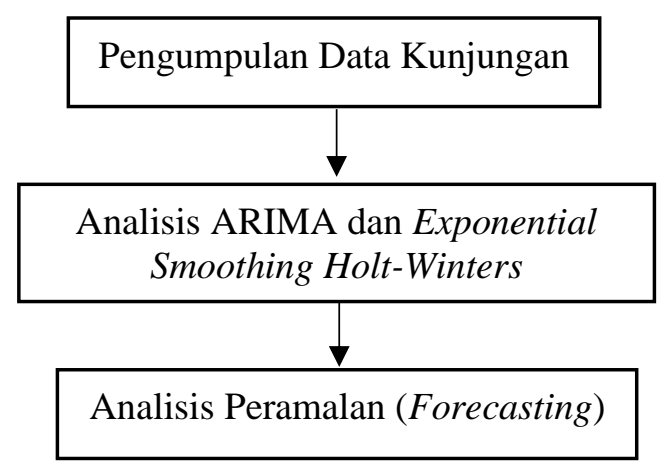

Gambar 3. Alir Diagram

Pada tahap pengumpulan data dilakukan penjumlahan data pengunjung, analisis kebutuhan data antara lain : (1) Sumber data yang digunakan dalam penelitian ini adalah data kunjungan di ACEP (Amikom Creative Economy Park) di masing-masing hari dalam bentuk waktu bulan selama 1 tahun yaitu bulan Januari-bulan Desember 2019; (2) Teknik pengumpulan data adalah dengan cara mengumpulkan data kuantitatif dari data pengunjung. Analisis pada penelitian ini menggunakan metode ARIMA dan Exponential Smoothing Holt-Winters untuk peramalan data kunjungan dan dilakukan perbandingan akurasi berdasarkan nilai MAPE. Analisis peramalan (forecasting) data kunjungan berdasarkan waktu yaitu bulan (diambil contoh 3 bulan di tahun 2020)

Tahapan metode ARIMA meliputi: (1) Pemeriksaan kestasioneran data; (2) Identifikasi model yang dianggap paling sesuai dengan menghitung dan menguji ACF dan PACF dai correlogram; (3) Tahap estimasi model dengan penaksiran terhadap parameter dalam model tersebut; (4) Tahap uji diagnostik: untuk menguji keseuaian dari model yang diperoleh pada tahap sebelumnya yaitu uji normalitas, uji heteroskedastisitas dan uji autokorelasi; (5) Penggunaan model untuk peramalan yang selanjutnya dihitung nilai MSE dan MAPE. (6) Melakukan Peramalan, setelah didapat model yang sesuai, maka selanjutnya melakukan peramalan menggunakan model tersebut sesuai dengan periode waktu peramalan yang di inginkan (dalam penelitian ini 3 periode waktu atau bulan).

Tahapan metode Exponential Smoothing Holt-Winters sendiri terdiri dari beberapa tahap yaitu: (1) mengambil data musiman; (2) membuat scatter diagram; (3) menetukan panjang musiman; (4) menentukan nilai awal taksiran (inisialisasi) pemulusan $(S L)$, trend $(b L)$ dan musiman $(I L)$; (6) menentukan nilai $\alpha, \beta, \gamma$ secara trial and error yang berada dalam range antara $0-1$; (7) Mencari nilai RMSE terkecil dari nilai $\alpha, \beta, \gamma$ yang kemudian dilakukan uji autokorelasi untuk mendapatkan model terbaik; (8) menghitung (St), (bt ) dan (It); (h) diperoleh hasil ramalan dan dihitung nilai MSE dan MAPE; (9) melakukan peramalan untuk 3 periode (3 bulan) ke depan.

\section{HASIL DAN PEMBAHASAN}

Pada Pembahasan hasil penelitian ini dilakukan dengan tahapan pengumpulan data terlebih dahulu, selanjutnya analisis dengan metode ARIMA dan Exponential Smoothing kemudian analisis forecasting dengan tujuan untuk mengetahui data peramalan pada tahun berikutnya.

\subsection{Pengumpulan Data}

Sumber data yang digunakan dalam penelitian ini adalah data kunjungan di ACEP (Amikom Creative Economy Park) di masing-masing hari dalam bentuk waktu bulan selama 1 tahun yaitu bulan Januari-bulan Desember 2019. Pada Tabel 1 berikut merupakan tahapan dalam pengumpulan data kunjungan: menjumlahkan data dalam bentuk hari kedalam bentuk data waktu bulan. 
Tabel 1. Contoh Data Transaksi Peminjaman Buku

\begin{tabular}{c|c}
\multicolumn{1}{c}{ BULAN } & $\begin{array}{c}\text { JUMLAH } \\
\text { PENGUNJUNG }\end{array}$ \\
\hline JANUARI & 41 \\
FEBRUARI & 42 \\
MARET & 21 \\
APRIL & 38 \\
MEI & 7 \\
JUNI & 21 \\
JULI & 20 \\
AGUSTUS & 26 \\
SEPTEMBER & 29 \\
OKTOBER & 32 \\
NOVEMBER & 45 \\
DESEMBER & 26 \\
&
\end{tabular}

\subsection{Analisis ARIMA dan Exponential Smoothing Holt-Winters}

Pada penelitian ini, akan dilakukan peramalan menggunakan data kunjungan di ACEP periode Januari 2019 - Desember 2019. Data kunjungan termasuk dalam data time series yang dapat diramalkan menggunakan metode ARIMA dan Exponential Smoothing. Data kunjungan membentuk pola trend yang ditunjukkan pada Gambar 4, yang dapat dilihat kunjungan mengalami penurunan di bulan mei 2019 serta mengalami kenaikan dibulan november 2019.

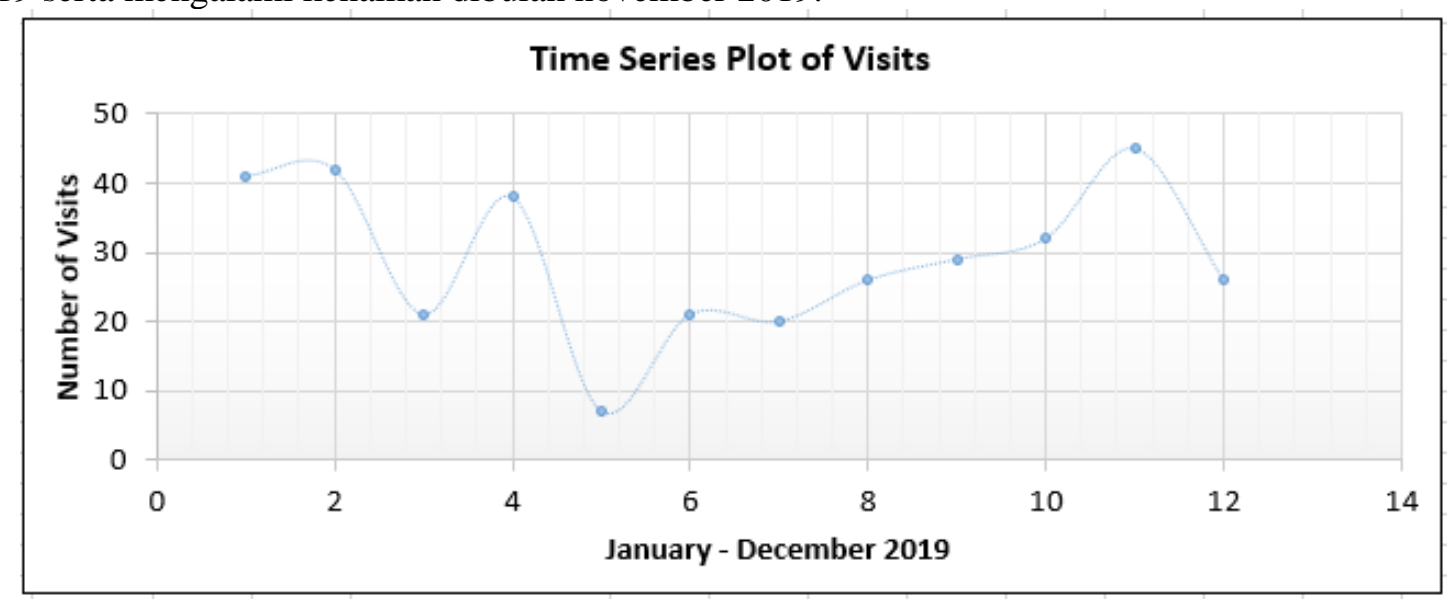

\subsubsection{Analisis ARIMA}

Gambar 4. Pola Trend Kunjungan

Pada data kunjungan ACEP terlihat data bersifat stasioner dengan adanya kecenderungan data menaik (ada unsur trend).

Terlihat pada Gambar 4 bahwa data mempunyai tinggi rendah yang tidak sama untuk setiap bulannya, hal ini menunjukkan bahwa data tidak stasioner di dalam varians. Oleh karena data tidak stasioner di dalam mean dan tidak stasioner dalam varians maka perlu dilakukan diffrencing dan transformasi. Data time series di-differencing dan transformasi dengan bantuan e-views (program komputer), hasil differencing dan transformasi ditunjukkan dalam plot time series Gambar 5. 


\begin{tabular}{|c|c|c|c|c|c|c|c|c|c|}
\hline \multicolumn{2}{|c|}{ Autocorrelation } & \multicolumn{3}{|c|}{ Partial Correlation } & \multicolumn{2}{|r|}{$\mathrm{AC}$} & \multirow{2}{*}{$\begin{array}{c}\text { PAC } \\
-0.627\end{array}$} & \multirow{2}{*}{$\frac{\text { Q-Stat }}{5.6219}$} & \multirow{2}{*}{$\frac{\text { Prob }}{0.018}$} \\
\hline$\sqsubset$ & 1 & ᄃ & & 1 & 1 & -0.627 & & & \\
\hline 1 & 1 & 1 & 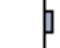 & 1 & 2 & 0.420 & 0.044 & 8.4204 & 0.015 \\
\hline 1 & 1 & 1 & 5 & 1 & 3 & -0.198 & 0.134 & 9.1219 & 0.028 \\
\hline 1 & 1 & 1 & 무 & 1 & 4 & -0.009 & -0.164 & 9.1236 & 0.058 \\
\hline 1 & 1 & 1 & 도 & 1 & 5 & 0.009 & -0.147 & 9.1254 & 0.104 \\
\hline $1 \square$ & 1 & 1 & & 1 & 6 & -0.279 & -0.440 & 11.355 & 0.078 \\
\hline 1 & 1 & 1 & 4 & 1 & 7 & 0.290 & -0.078 & 14.360 & 0.045 \\
\hline$\square$ & 1 & 1 & 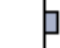 & 1 & 8 & -0.243 & 0.084 & 17.172 & 0.028 \\
\hline 1 & 1 & 1 & ᄃ & 1 & 9 & 0.155 & -0.090 & 18.890 & 0.026 \\
\hline 1 & 1 & 1 & 다 & 1 & 10 & -0.017 & -0.087 & 18.932 & 0.041 \\
\hline
\end{tabular}

\section{Gambar 5. Correlogram Hasil Differencing kedua dan Transformasi Logaritma}

Berdasarkan Gambar 5 plot data hasil differencing dan transformasi, diperoleh bahwa data sudah cenderung jauh lebih baik. Uji stasioner dapat dilakukan dengan melihat plot data tidak stasioner dalam mean dan variansi, correlogram grafik ACF dan PACF dan nilai uji akar unit. Uji akar unit (Unit Root Test) digunakan untuk menguji kestasioneran data yang dikembangkan oleh Dickey-Fuller[3]. Uji ini dilakukan untuk menguji adanya anggapan bahwa sebuah data time series tidak stasioner pada Gambar 5.

\begin{tabular}{lccc}
\hline \hline & t-Statistic & Prob. \\
\hline \hline Augmented Dickey-Fuller test statistic & -6.147471 & 0.0009 \\
\hline Test critical values: $\quad 1 \%$ level & -4.297073 & \\
& $5 \%$ level & -3.212696 & \\
& $10 \%$ level & -2.747676 & \\
\hline \hline
\end{tabular}

*MacKinnon (1996) one-sided p-values.

\section{Gambar 6. Uji Akar Unit}

Berdasarkan Gambar 6, nilai mutlak ADF Test Statistic yakni 6,147471 yang lebih dari nilai statistik t dengan nilai kritis $\alpha=5 \%$ adalah 3,212696 yang rtinya, H0 ditolak, hal ini menunjukkan bahwa data telah stasioner. Data stasioner diatas dilakukan 2 kali differencing, karena differencing yang pertama probabilitasnya 0,0618 sedangkan dalam differenceng kedua nilai probabilitasnya 0,0009.

Setelah melakukan tahapan identifikasi, diketahui data jumlah data kunjungan di ACEP tidak stasioner dalam mean dan varian. Data tersebut stasioner setelah dilakukan differencing dua kali pada pola musiman dan non-musiman dengan transformasi logaritma.

Identifikasi tahap berikutnya yaitu estimasi. Pada tahap ini terlihat keakuratan dari beberapa model-model tentatif bahwa model terbaik ARIMA diperoleh dengan kriteria meminimumkan galat (error) terkecil[4].

Langkah estimasi parameter dari model-model dengan melakukan uji hipotesis untuk setiap parameter yang dimiliki setiap model pada output Gambar 7. Uji Signifikansi Parameter $\operatorname{ARIMA}(2,1,0)(0,1,1)$ dengan transformasi logaritma yaitu:

- Uji parameter AR(1)

a) Hipotesis: H0 : Parameter sama dengan nol atau tidak signifikan H1 : Parameter sama dengan nol atau signifikan

b) Nilai koefisien AR(1) sebesar -0,674436

c) Tingkat signifikansi $(\alpha)=5 \%=0,05$

d) Statistik uji: Probabilitas $=0,1515$

e) Daerah kritis: H1 ditolak jika probabilitas > 0,05 Kesimpulan: Dari estimasi diperoleh nilai probabilitas 0.1515 .

- Uji parameter AR(2) 
a) Hipotesis: H0 : Parameter sama dengan nol atau tidak signifikan H1 : Parameter sama dengan nol atau signifikan

b) Nilai koefisien $\operatorname{AR}(2)$ sebesar 0.295268

c) Tingkat signifikansi $(\alpha)=5 \%=0,05$

d) Statistik uji: Probabilitas $=0,4338$

e) Daerah kritis: Ho diterima jika probabilitas $>0,05$

Kesimpulan: Dari estimasi diperoleh nilai probabilitas 0.4338

\begin{tabular}{lrlrr}
\hline \hline \multicolumn{1}{c}{ Variable } & Coefficient & Std. Error & t-Statistic & Prob. \\
\hline \hline C & -0.982619 & 3.463799 & -0.283682 & 0.7862 \\
AR(1) & -0.674436 & 0.410528 & -1.642851 & 0.1515 \\
AR(2) & 0.295268 & 0.352088 & 0.838621 & 0.4338 \\
AR(3) & 0.362710 & 0.321525 & 1.128093 & 0.3024 \\
SIGMASQ & 105.0102 & 77.86817 & 1.348564 & 0.2262 \\
\hline \hline R-squared & 0.529015 & Mean dependent var & -1.363636 \\
Adjusted R-squared & 0.215025 & S.D. dependent var & 15.66060 \\
S.E. of regression & 13.87511 & Akaike info criterion & 8.499786 \\
Sum squared resid & 1155.112 & Schwarz criterion & 8.680647 \\
Log likelihood & -41.74882 & Hannan-Quinn criter. & 8.385778 \\
F-statistic & 1.684814 & Durbin-Watson stat & 1.917175 \\
Prob(F-statistic) & 0.270287 & & & \\
\hline \hline Inverted AR Roots & .65 & -.66 -.35i & -.66+.35i \\
\hline \hline
\end{tabular}

Gambar 7. Equation Specification

\subsubsection{Analisis Exponential Smoothing Holt-Winters}

Model time series dengan metode Exponential Smoothing-Holt Winters dengan plot data kunjungan.

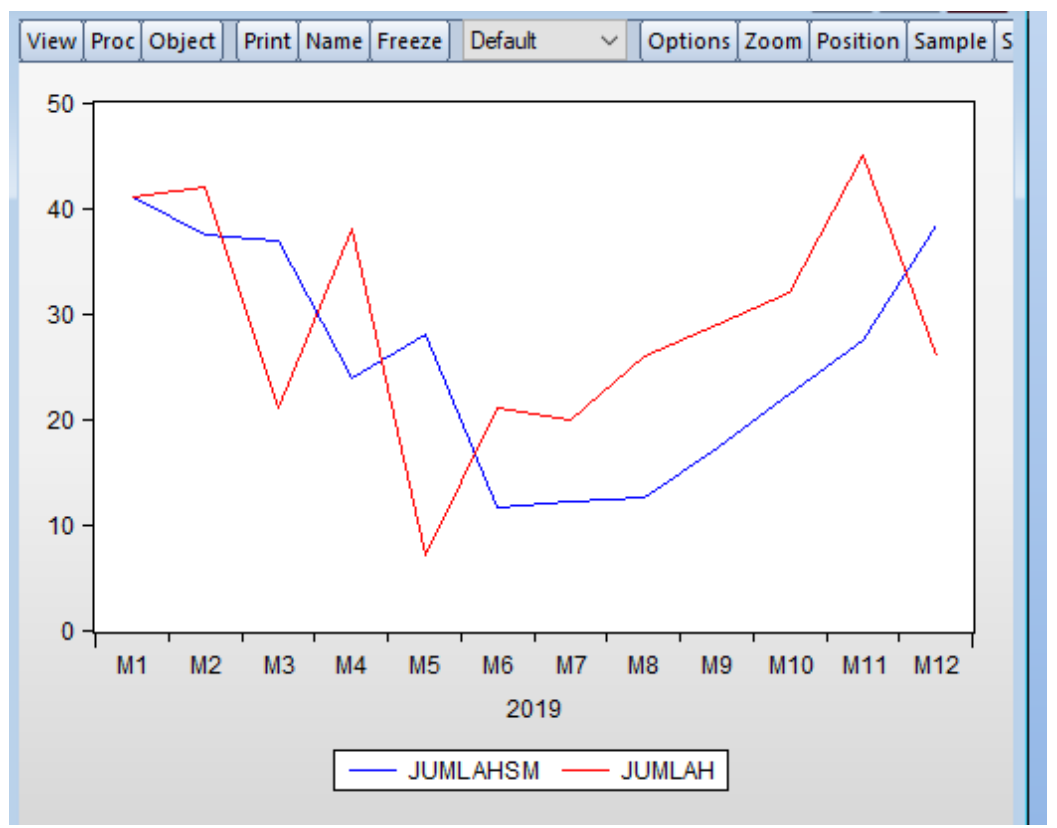

Gambar 8. Output hasil Exponential Smoothing

Berdasarkan Gambar 8 terlihat pola data merah (hasil Holt-Winters) pemulusan pola data musiman yang ada pada data aktual, khususnya pada tahun 2019. Secara deskriptif jumlah data kunjungan akan mengalami peningkatan. Gambar 9 dapat dilihat untuk nilai $\alpha$ dan $\gamma$. Didapatkan nilai $\alpha=0.52, \beta=0.200$ dan $\gamma=0.5384$. 


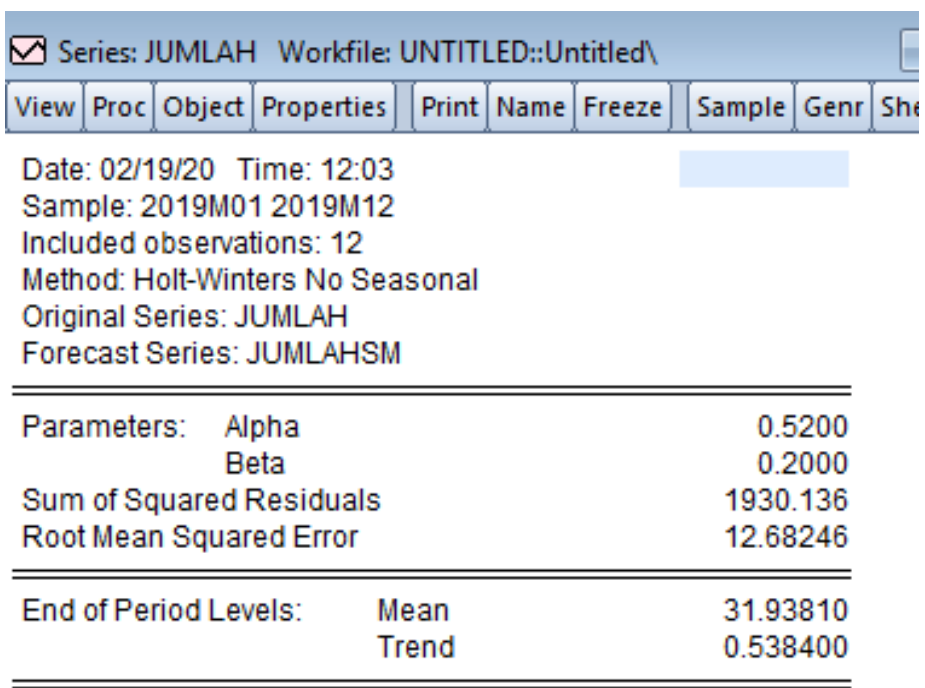

\section{Gambar 9. Ouput nilai $\alpha, \beta$ dan $\gamma$}

Seleksi model Exponential Smoothing Holt-Winters dilakukan uji autokorelasi. Pengujian autokorelasi pada error (residu) perlu dilakukan untuk mengetahui apakah error (residu) bersifat random dan tidak ada korelasi yang nyata antar error. Dari 12 model diuji apakah terdapat korelasi antar error (residu). Pada uji autokorelasi, semakin besar nilai beta $(\beta)$ dan gamma $(\gamma)$ maka akan terjadi adanya korelasi sehingga jika terjadi auotokorelasi maka model belum dikatakan menjadi model terbaik. Model dikatakan model terbaik jika mempunyai nilai RMSE terkecil dan tidak terjadi autokorelasi dengan kriteria nilai probabilitas Chi-Square dari Observasi R-Squared lebih dari atau sama dengan p-value yaitu 0,05 .

\subsection{Analisis Forecasting}

\section{Efektivitas Metode untuk Meramalkan Data Kunjungan}

Berikut ini adalah hasil peramalan tiga bulan berikutnya (data ke 13, 14, dan 15) berdasarakan data dari bulan Januari 2019 sampai Desember 2019.

Peramalan dilakukan menggunakan metode ARIMA dan Exponential Smoothing.

Tabel 2. Hasil Peramalan

PERAMALAN JANUARI FEBRUARI MARET

(13) $\quad$ (14) $\quad$ (15)

\begin{tabular}{l|ccc} 
ARIMA & 40.01 & 39.03476 & 38.05214 \\
EXPONENTIAL & 41 & 37.5 & 36.8 \\
SMOOTHING & & &
\end{tabular}

Nilai MSE (Mean Square Error) pada hasil peramalan menggunakan metode ARIMA dan Exponential Smoothing ditunjukkan Tabel 2. MSE digunakan untuk mengukur ketepatan nilai dugaan model yang dinyatakan dalam rata-rata kuadrat dari kesalahan.

Tabel 3. Nilai MSE

\begin{tabular}{|cc|}
\hline Metode & Nilai MSE \\
ARIMA & 11.160 \\
Exponential Smoothing & 11.475 \\
\hline
\end{tabular}

Pemilihan model terbaik untuk keefektivitasan kedua metode selain menggunakan nilai MSE dapat menggunakan nilai MAPE. MAPE digunakan untuk mengukur ketepatan nilai dugaan model yang dinyatakan dalam bentuk rata-rata persentase absolute kesalahan. Nilai MAPE (Mean Absolute Percentage Error) dari hasil peramalan menggunakan metode ARIMA dan metode Exponential Smoothing ditunjukkan Tabel 3. 
Tabel 4. Nilai MAPE

\begin{tabular}{|cc|}
\hline Metode & Nilai MAPE \\
ARIMA & 48.949 \\
Exponential Smoothing & 47.197 \\
\hline
\end{tabular}

Dari Tabel 4 menunjukkan bahwa eror dari metode ARIMA lebih kecil dibandingkan dengan metode Exponential Smoothing, sehingga model yang paling baik untuk meramalkan data kunjungan di ACEP adalah dengan menggunakan metode ARIMA.

Dalam bahasan diatas ada 12 data bulan, sedangkan berikut dilakukan perhitungan dengan bantuan software SPSS, berdasarkan jumlah data kunjungan dengan jangka waktu 12 bulan, 24 bulan dan 36 bulan yang didapatkan dan dengan mengamati perbandingan nilai MSE dan MAPE dimasing-masing metode.

Tabel 5. Perbandingan Nilai MSE dan MAPE berdasarkan data waktu

\begin{tabular}{|lllllll|}
\hline & \multicolumn{2}{c}{ Waktu 12 Bulan } & \multicolumn{2}{c|}{ Waktu 24 Bulan } & \multicolumn{2}{c|}{ Waktu 36 Bulan (3 } \\
Perbandingan & \multicolumn{2}{c}{ (1 Tahun) } & \multicolumn{2}{c|}{ (2 Tahun) } & \multicolumn{2}{c}{ Tahun) } \\
& Nilai & NILAI & Nilai & NILAI & Nilai & NILAI \\
& MSE & MAPE & MSE & MAPE & MSE & MAPE \\
ARIMA & 11.160 & 48.949 & 12.256 & 78.016 & 12.104 & 68.182 \\
$\begin{array}{l}\text { Exponential } \\
\text { Smoothing }\end{array}$ & 11.475 & 47.197 & 12.475 & 76.537 & 12.475 & 66.134 \\
\hline
\end{tabular}

Dari Tabel 5 dapat diketahui bahwa dengan menggunakan jumlah data kunjungan yang berbeda-beda dengan durasi waktu 12 bulan, 24 bulan dan 26 bulan, maka dapat diketahui jika metode Exponential Smoothing memiliki nilai MAPE lebih kecil dibandingkan nilai MAPE metode ARIMA. Dari Tabel 5 perbandingan antara 2 metode memiliki kesimpulan metode Exponential Smoothing lebih akurat dalam melakukan peramalan kunjungan selanjutnya.

\section{KESIMPULAN}

Hasil penelitian perbandingan metode dapat diamati dengan melihat efektivitas model dari besar nilai MSE dan MAPE pada kedua metode yang digunakan. Dalam penelitian ini menggunakan sample data kunjungan, sehingga hasil peramalan jumlah data kunjungan di Amikom Creative Economy Park dengan metode Exponential Smoothing Holt-Winters menghasilkan nilai Mean Square Error (MSE) yaitu 11,475 dan nilai Mean Absolute Percentage Error (MAPE) yaitu 47.197.

Sedangkan metode ARIMA menghasilkan nilai Mean Square Error (MSE) yaitu 11,160 dan nilai Mean Absolute Percentage Error (MAPE) yaitu 48.949. Jadi peramalan jumlah data kunjungan periode bulan Januari-Desember 2019 lebih akurat menggunakan metode Exponential Smoothing Holt-Winters dibandingkan metode ARIMA karena nilai MAPE yang lebih kecil daripada nilai MAPE yang dihasilkan metode ARIMA. Keakuratan dalam memperamalan sangat penting dilakukan, mengingat hasil peramalan dalam suatu data akan dapat digunakan untuk menentukan strategi langkah selanjutnya yang tepat dalam data peramalan yang sudah dilakukan uji analisis. Angka peramalan yang didapat juga dapat membantu melakukan pengambilan keputusan yang tepat.

\section{REFERENSI}

[1] M. Suyanto and F. Wibowo, "Animation Opportunities of Intellegent Multimedia System in Developing a Creative Economy Park," 2018, pp. 69-74.

[2] M. Y. Istiqomah, Widia., Darsyah, "Akuratitas Metode Arima dan Exponential Smoothing Untuk Meramalkan Nilai Tukar Petani di Jawa Tengah,” vol. 1, 2018.

[3] Turban.E, Decision Support Systems and Intelligent Systems Edisi Bahasa Indonesia Jilid 1. Yogyakarta: Andi, 2005.

[4] D. T. Larose, Discovering Knowledge in Data : An Introduction to Data Mining. John Willey \& Sons, Inc, 2005. 
[5] U. Fayyad, Advances in Knowledge Discovery and Data Mining. MIT Press.

[6] D. Putro, Bossarito, "Peramalan Jumlah Kebutuhan Pemakaian Air Menggunakan Metode Exponential Smoothing," J. Pengemb. Teknol. Inf. dan Ilmu Komput., vol. 2, no. 11, pp. 46794686.

[7] D. Suyanto, Data Mining Untuk Klasifikasi dan Klasterisasi Data. Bandung: Informatika, 2017.

[8] D. Aziz, Syarfi., "Penerapan Metode ARIMA untuk Peramalan Pengunjung Perpustakaan UIN Suska Riau," 2017, p. 9.

[9] Direktorat Kehumasan dan Urusan Internasional Universitas AMIKOM Yogyakarta, "Data Kunjungan (Studi Visit)," Data Kunjungan, 2019. http://www.humas.amikom.ac.id. (accessed Jan. 02, 2020).

[10] L. D. Lingitz, "Lead time prediction using machine learning algorithms: A case study by semiconductor manufactur," Elsivier, vol. 72, no. Procedia CIRP, pp. 1051-1056, 2018.

[11] D. Hanke, J.E., Business Forecasting. New Jersey: Pearson Education International, 2005.

[12] S. Haryati, "Implementasi Data Mining Untuk Memperamalan Masa Studi Mahasiswa Menggunakan Algoritma C4.5 (Studi Kasus: Universitas Dehasen Bengkulu)," J. Media Infotama, vol. 11, no. 2, pp. 130-138.

[13] dan V. E. M. Makridakis, Spyros., Steven C. Wheelwright, Metode dan Aplikasi Peramalan. Jakarta: Erlangga, 1999.

[14] B. S. . Machmudin, A., Ulama, "Peramalan Temperatur Udara di Kota Surabaya dengan Menggunakan ARIMA dan Artificial Neural Network," J. Sains dan Seni ITS, vol. 1 (1), pp. 118-123, 2012.

[15] T. Safitri, "Perbandingan Peramalan Menggunakan Metode Exponential Smoothing HoltWinters Dan Arima," J. Math. UJM, vol. 6, no. 1, pp. 45-58, 2017. 